\begin{tabular}{cc|c}
\hline Tar. Bil. Der. & Tarm Bilimleri Dergisi & Journal of Agricultural Sciences \\
& $\begin{array}{c}\text { Dergi web sayfası: } \\
\text { www.agri.ankara.edu.tr/dergi }\end{array}$ & Journal homepage: \\
& www.agri.ankara.edu.tr/journal
\end{tabular}

\title{
Grain Yield and Some Physiological Traits Associated with Heat Tolerance in Bread Wheat (Triticum aestivum L.) Genotypes
}

\author{
Zahit Kayıhan KORKUT ${ }^{\mathrm{a}}$, Alpay BALKAN ${ }^{\mathrm{a}}$, İsmet BAŞER ${ }^{\mathrm{a}}$, Oğuz BILLGIN ${ }^{\mathrm{a}}$ \\ ${ }^{\boldsymbol{a}}$ Tekirdă̆ Namık Kemal University, Agricultural Faculty, Department of Field Crops, 59030, Tekirdă̆, TURKEY
}

\section{ARTICLE INFO}

Research Article

DOI: 10.15832 ankutbd.448626

Corresponding Author: Alpay BALKAN, E-mail: abalkan@nku.edu.tr, Tel: +90 (282) 2502148

Received: 27 July 2018, Received in Revised Form: 27 August 2018, Accepted: 08 September 2019

\begin{abstract}
This research was carried out in the experimental fields of Department of Field Crops, Faculty of Agriculture, the University of Namık Kemal in 2014-2015. In the study, totally 30 bread wheat (Triticum aestivum L.) genotypes (15 cultivars; early, medium-early and late-maturing; 10 lines are tolerant to the heat-temperature stress which were provided by CIMMYT-International Maize and Wheat Improvement Center), 5 lines (were taken from the same university's wheat breeding program which was collaborated by the CIMMYT) were used as an experimental material. The experiment was adjusted in a split-plot design with 3 replicates. Sowing dates (Normal (NS $\approx$ November 09, 2014) and Late sowing (LS $\approx$ January 09,2015$)$ ) were constituted the main plots, and the genotypes constituted the sub-plots. These physiological traits ((membrane thermostability (MT), canopy temperature (CT), leaf chlorophyll content (LCC) and stomatal conductance (SC)) were measured at the LS stage due to giving much more correct, logical and meaningful results, but grain yield (GY) was fixed for all the sowing dates. Obtained findings are: The GY was varied between (4.35$\left.6.34 \mathrm{t} \mathrm{ha}^{-1}\right)$ for genotypes; the MT was changed between (10.58-66.25\%); the CT was realized between $\left(17.67-22.00^{\circ} \mathrm{C}\right)$; the LCC was varied between (38.30-53.30 SPAD) and the SC was changed between (25.20-166.80 $\left.\mathrm{mmol} \mathrm{m}^{-2} \mathrm{~s}^{-1}\right)$. It was observed that most of the CIMMYT originated genotypes are tolerant to high-temperature stress and most of the wheats that are grown in Thrace Region are negatively affected by the high-temperature stress.

Keywords: Heat tolerance; Canopy temperature; Chlorophyll content; Membrane thermostability; Stomatal conductance
\end{abstract}

(C) Ankara Üniversitesi Ziraat Fakültesi

\section{Introduction}

Bread wheat (Triticum aestivum L.) is one of the oldest and most important staple foods of the world agriculture because of its high adaptation ability, stress-tolerant genotypes, easy transportation and storage. It has expanded in quite different ecologies, undergoes many restrictive abiotic stress factors. Abiotic stress factors negatively influence the growing and grain yield by causing morphological, physiological, biochemical and molecular changes (Wang et al 2001). The stress factors such as high temperatures, salinity, and drought which occurred as a result of global climate change that has been highly felt in recent years influence plant yield quite a lot (Mathur \& Jajoo 2014).

The abiotic stress conditions such as hightemperature stress are being threatened to agriculture and agricultural fields in many regions in the world 
(Wang et al 2003). In addition, cultivated many plants grow well between $\left(15-45^{\circ} \mathrm{C}\right)$ temperature limits, and in outside of these limits their growth, development, metabolism, quality and quantity, etc. are highly (negatively) affected depending on regions. However, under high-temperature conditions, heading or flowering of plants may be negatively influenced, abnormalities such as pollen viability reduce, flower shedding happens, respiration, photosynthesis, fertilization evens decreases, and finally all of them stop (Balla et al 2011). Besides, Kirby et al (1985) and Longnecker et al (1993) stated that plants react differently to high-temperature stress in different phenological periods, and their development and survival durations depend on genotype, growing duration, cultivation technique applications and especially the temperature of the region in which they grow.

The researches revealed that the yield decrease which is caused by high-temperature stress in the development process of wheat is related to the decrease in the number and weight of grains per spike (Hays et al 2007). Reynolds et al (1994) explained that high-temperature stress in temperate environments is an important restrictive factor in heading and grain filling periods. Balla et al (2011) identified that high temperature is the most effective factor at the early embryo development stage in bread wheat. The reductive effects of high temperature on grain yield were revealed by Bluementhal et al (1995) and Wardlaw et al (2002). Kosina et al (2007) stated that high temperatures at heading and grain filling stages caused significant decreases in grain size and weight. Mentioned researchers' studies of wheat's tolerance to hightemperature stress, to know the physiological traits of genotypes which they use to resistance hightemperature stress will increase the effectiveness of breeding programs in the improvement of new high-temperature tolerant genotypes. Reynolds et al (2001) manifested that the LCC of bread wheat and high photosynthesis rate, stay-green duration, CT, MT and SC are physiological traits that are related to wheat's tolerance to the high-temperature stress.
The aim of this study is to identify the effects of high-temperature stress on the grain yield and selected physiological traits and to detect and use them as selection criteria for the high-temperature tolerant wheat breeding programs as genitor.

\section{Material and Methods}

\subsection{Experimental site and growing conditions}

This research was conducted out at the University of Tekirdağ Namık Kemal, Faculty of Agriculture, Department of Field Crops, Tekirdağ, Turkey in the 2014-2015. Geographically, Tekirdağ district locates at latitude $40^{\circ} 36^{\prime}-40^{\circ} 31^{\prime}$ and longitude $26^{\circ} 43^{\prime}-28^{\circ}$ $08^{\prime}$ and asl is $10 \mathrm{~m}$. The mean temperature, total rainfall and relative humidity in the 2014-2015 with long-term means are presented in Table 1. As seen in Table 1, the mean temperature in November 2014 and July 2015 is $13.1{ }^{\circ} \mathrm{C}$ and the long-term annual mean value since this period is $12.7^{\circ} \mathrm{C}$. While the total temperature is $915.4^{\circ} \mathrm{C}$ during a heading-maturation stage in the NS; in the LS, total temperature becomes $1084.8{ }^{\circ} \mathrm{C}$ during the heading-maturation stage. The difference between the total temperature in a heading-maturation stage in the NS and in a headingmaturation stage in the LS is $169.4{ }^{\circ} \mathrm{C}$. Likewise, while the total rainfall is $62.1 \mathrm{~mm}$ during a headingmaturation stage in the NS, in the LS total rainfall becomes $88.6 \mathrm{~mm}$ during the heading-maturation stage. The difference between the total rainfall in a heading-maturation stage in the NS and in a headingmaturation stage in the LS is $26.5 \mathrm{~mm}$.

According to soil analysis results, experimental area's soil was clay-loam, slightly acidic ( $\mathrm{pH}$ 6.5), limeless, and poor (1.08\%) in the organic matter.

\subsection{Experimental materials and design}

Thirty bread wheat (Triticum aestivum L.) genotypes were used as experimental material in this study. They are (15) registered cultivars (Namely, Nota, Kate A1, Basribey, Gelibolu, Esperia, Saraybosna, Syrena, Flamura 85, Krasunia, Dropia, Tina, Golia, Tekirdağ, Pehlivan and Yubileynaya 100) with different phenological and agronomical traits (such as early maturing, medium-early maturing and late 
Table 1- Some meteorological parameters during the 2014-2015

\begin{tabular}{|c|c|c|c|c|c|c|}
\hline \multirow[b]{2}{*}{ Months } & \multirow{2}{*}{$\begin{array}{r}\text { Mean temp. } \\
\left({ }^{\circ} \mathrm{C}\right)\end{array}$} & \multirow{2}{*}{$\begin{array}{r}\text { Rainfall } \\
(\mathrm{mm})\end{array}$} & \multirow{2}{*}{$\begin{array}{r}\text { Humidity } \\
(\%)\end{array}$} & \multicolumn{3}{|c|}{ Long-Term } \\
\hline & & & & $\begin{array}{r}\text { Mean temp. } \\
\left({ }^{\circ} \mathrm{C}\right)\end{array}$ & $\begin{array}{r}\text { Rainfall } \\
(\mathrm{mm})\end{array}$ & $\begin{array}{r}\text { Humidity } \\
(\%)\end{array}$ \\
\hline November-2014 & 11.2 & 35.2 & 85.2 & 11.3 & 62.5 & 84.0 \\
\hline December-2014 & 9.3 & 80.3 & 89.1 & 7.2 & 82.5 & 83.6 \\
\hline January-2015 & 5.8 & 61.5 & 81.9 & 5.2 & 62.1 & 84.0 \\
\hline February-2015 & 6.5 & 90.3 & 86.0 & 5.7 & 64.9 & 81.4 \\
\hline March-2015 & 8.5 & 29.4 & 81.9 & 8.0 & 57.4 & 80.7 \\
\hline April-2015 & 11.4 & 60.1 & 74.3 & 12.2 & 41.5 & 78.2 \\
\hline May-2015 & 18.6 & 1.4 & 76.3 & 17.6 & 33.8 & 75.1 \\
\hline June-2015 & 21.3 & 58.4 & 73.3 & 22.2 & 35.0 & 72.6 \\
\hline July-2015 & 24.9 & 0.5 & 70.6 & 25.0 & 26.7 & 69.6 \\
\hline Total & - & 417.1 & - & - & 466.4 & - \\
\hline Mean & 13.1 & - & 79.8 & 12.7 & - & 78.8 \\
\hline
\end{tabular}

Total temperature is $915.4^{\circ} \mathrm{C}$ and total rainfall is $62.1 \mathrm{~mm}$ during a heading-maturity stage under the NS conditions.

Total temperature is $1084.8^{\circ} \mathrm{C}$ and total rainfall is $88.6 \mathrm{~mm}$ during a heading-maturity stage under the LS conditions.

Source, Tekirdağ meteorology station

maturing); (10) lines obtained from the Heat Tolerance Nursery (HTN) of CIMMYT (International Maize and Wheat Improvement Center-Mexico) collection which are known as tolerant to the heat-temperature stress (CIMMYT-HTN 2014/15-1, CIMMYT-HTN 2014/ 15-2, CIMMYT-HTN 2014/15-3, CIMMYT-HTN 2014/15-4, CIMMYT-HTN 2014/15-5, CIMMYT-HTN 2014/15-6, CIMMYT-HTN 2014/15-7, CIMMYTHTN 2014/15-8, CIMMYT-HTN 2014/15-9 and CIMMYT-HTN 2014/15-10) and (5) lines are (CIMMYT-HTN 2013/14-4464, CIMMYT-HTN 2013/ 14-4488, CIMMYT-HTN 2013/14-4489, CIMMYTHTN 2013/14-4490 and CIMMYT-HTN 2013/144492). Except them, Basribey bread wheat was used as a standard "tolerant" cultivar to the high-temperature stress in this study.

On the other hand, to be able to synchronize of growth stages, the experiment was arranged in a split-plot design with 3 replicates at two sowing dates (Normal sowing date $\approx 09$ November 2014 and Late sowing time date $\approx 09$ January 2015). Sowing dates were adjusted as main plots and genotypes were allotted as subplots. Sowing procedure was done in $1.2 \mathrm{~m} \mathrm{x} 5 \mathrm{~m}$ plots, consisted of 6 rows spaced $20 \mathrm{~cm}$ apart. The seeding rate was arranged as 500 seeds $\mathrm{m}^{-2}$ and 20.20 .0 composed fertilizer was used which include $50 \mathrm{~kg} \mathrm{ha}^{-1}$ pure nitrogen (N) and $50 \mathrm{~kg} \mathrm{ha}^{-1}$ pure phosphor $\left(\mathrm{P}_{2} \mathrm{O}_{5}\right)$ was with the sowing. In addition to this, $60 \mathrm{~kg} \mathrm{ha}^{-1}$ pure $\mathrm{N}$ as urea fertilizer $(46 \% \mathrm{~N})$ at the tillering stage and 50 $\mathrm{kg} \mathrm{ha}^{-1}$ pure $\mathrm{N}$ as ammonium nitrate fertilizer $(33 \%$ $\mathrm{N})$ at the stem elongation stage were also given. Moreover, chemical control method was applied between tillering and stems elongation stages in spring considering the maturation condition and density of the prevalent weeds such as ryegrass (Lolium multiflorum), creeping thistle (Cirsium arvense), finger speedwell (Veronica triphyllos), wild mustard (Sinapis arvensis). All plots were harvested with a HEGE-160 combine harvester on the July 2015 during the maturity.

\subsection{Measurement of grain yield and physiological traits}

Grain Yield ( $\left.\mathrm{t} \mathrm{ha}^{-1}\right)$ : After $0.5 \mathrm{~m}$ pieces were cut from the beginnings and endings of the plots at the maturity (Zadoks Growth Stage (ZGS) 93; Zadoks et al 1974), and obtained values were transformed into $t$ ha $^{-1}$. In addition, all the physiological traits presented below were a measured at the post-anthesis periods of the plants (ZGS 69; Zadoks et at 1974). 
Membrane Thermostability (MT-\%): It was fixed as $(\%)$ in the fully-developed flag leaves according to Reynolds et al (2001).

Canopy Temperature $\left(\mathrm{CT}-{ }^{\circ} \mathrm{C}\right)$ : It was measured with a portable infrared thermometer (Extech Mini IR Thermometer Modell 42500) as ${ }^{\circ} \mathrm{C}$ (Reynolds et al 2001). It was taken as two measurements per plot during the day between (11:00h to 14:00h).

Leaf Chlorophyll Content (LCC-SPAD): It was measured with "Konica Minolta SPAD-502 Plus" portable chlorophyll meter in the fully-developed flag leaves and determined as "SPAD value" (Pask et al 2012). It was taken three averages of five leaves per plot, and they were done from 11:00h to 14:00h.

Stomatal Conductance ( $\mathrm{SC}-\mathrm{mmol} \mathrm{m} \mathrm{m}^{-2} \mathrm{~s}^{-1}$ ): It was measured with a portable leaf porometer (Decagon SC-1 Leaf Porometer) and determined as $\mathrm{mmol} \mathrm{m}{ }^{-2}$ $\mathrm{s}^{-1}$ by calculating the average (Pask et al 2012). It was taken three readings on different, randomly chosen leaves from each plot. Readings were done from 11:00h to 14:00h.

\subsection{Statistical analysis}

All the data obtained from this experiment were subjected to variance analysis (ANOVA) using MSTAT-C statistical software, and mean values were compared using Duncan's Multiple Range Test (Steel \& Torrie 1960).

\section{Results and Discussion}

In the experiment, obtained data for the GY were combined and analyzed to compare the GY performance of bread wheat genotypes under the NS and LS (heat-temperature stress). Whereas, the physiological traits associated with heat tolerance mechanisms which MT, CT, LCC and SC were determined under the LS conditions (Table 3).

Grain yield $\left(\mathrm{t} \mathrm{ha}^{-1}\right)$ : The effect of sowing date for the GY was not statistically significant, but genotype and sowing date $\mathrm{x}$ genotype interaction was statistically significant $(\mathrm{P} \leq 0.01)$ in terms of the GY (Table 2). Although the difference between sowing dates for the GY was not statistically significant, the mean of GY which was determined as $5.76 \mathrm{t} \mathrm{ha}^{-1}$ in the NS, decreased around $7.8 \%$ in the LS and was determined as $5.31 \mathrm{t} \mathrm{ha}^{-1}$. It was taken more rainfall in the LS than NS during headingmaturity stages. However, as it can be understood from Table 1, plants were exposed $169.4{ }^{\circ} \mathrm{C}$ higher temperature during heading-maturity stages in the LS comparing to the NS. This situation caused stress, early senescence and decrease in grain filling stage. Thus, in the LS, the lower GY $\left(5.31 \mathrm{tha}^{-1}\right)$ was obtained with the influence of hightemperature stress. Similarly, Mohammadi et al (2004) found out that the high-temperature stress at the post-anthesis stage of wheat decreases the grain filling duration, and the grain and head weight, but it does not influence of grain number per spike. Din et al (2010) discovered that the GY decreased 53.75\% at the LS conditions. Modhej et al (2015) revealed that the high-temperature stress occurred at the LS conditions as decreases in the GY 30\%, and 1000 grain weight.

In the research, the mean of the GY (for the genotypes) varied between 4.35 to $6.34 \mathrm{t} \mathrm{ha}^{-1}$. The highest GY was obtained from CIMMYT-HTN 2014/15-5 (6.34 t ha-1). It was followed by Basribey (6.22 $\left.\mathrm{t} \mathrm{ha}^{-1}\right)$, CIMMYT-HTN 2014/15-1 (6.21 $\left.\mathrm{t} \mathrm{ha}^{-1}\right)$, CIMMYT-HTN 2014/15-4 (6.20 t ha-1) and Nota (6.19 $\left.\mathrm{t} \mathrm{ha}^{-1}\right)$, but the lowest GY was observed in CIMMYT-HTN 2014/15-7 (4.35 $\left.\mathrm{t} \mathrm{ha}^{-1}\right)$ and it was followed by CIMMYT-HTN 2014/15-10 (4.43 t ha $\left.{ }^{-1}\right)$ (Table 2). In the research, it has been realized that the lines obtained from the CIMMYT and having high heat tolerance have high the GY.

The highest GY in the NS was obtained from CIMMYT-HTN 2013/14-4492 (6.87 t ha $\left.{ }^{-1}\right)$. It was followed by CIMMYT-HTN 2013/14-4489 (6.85 t ha $\left.^{-1}\right)$, Nota (6.76 t ha-1), CIMMYT-HTN 2014/155 (6.73 t ha $\left.{ }^{-1}\right)$, CIMMYT-HTN 2013/14-4488 (6.63 $\left.\mathrm{t} \mathrm{ha}^{-1}\right)$, Basribey (6.46 $\left.\mathrm{t} \mathrm{ha}^{-1}\right)$, Yubileynaya 100 $\left(6.39 \mathrm{t} \mathrm{ha}^{-1}\right)$, Tina and Flamura $85\left(6.09 \mathrm{t} \mathrm{ha}^{-1}\right)$, and CIMMYT-HTN 2013/14-4490 (6.06 t ha-1) (Table 2). The GY performances of bread wheat genotypes which were used for the LS date, they were exposed to high-temperature stress at the post-anthesis stage were lower than normal sowing date. The genotype 
Table 2- Mean values and statistically significance groups for the GY (t ha-1)

\begin{tabular}{|c|c|c|c|c|}
\hline \multirow{2}{*}{ Genotype } & \multicolumn{2}{|c|}{ Sowing date } & \multirow{2}{*}{$\begin{array}{l}\text { Change } \\
\text { rate (\%) }\end{array}$} & \multirow{2}{*}{ Mean } \\
\hline & $N$ & $L$ & & \\
\hline CIMMYT-HTN 2014/15-1 & $6.37 \mathrm{a}-\mathrm{f}$ & $6.06 \mathrm{a}-1$ & -4.87 & $6.21 \mathrm{ab}$ \\
\hline CIMMYT-HTN 2013/14-4489 & $6.85 \mathrm{a}$ & $5.19 \mathrm{j}-\mathrm{t}$ & -24.23 & $6.02 \mathrm{a}-\mathrm{d}$ \\
\hline CIMMYT-HTN 2014/15-5 & $6.73 \mathrm{abc}$ & $5.95 \mathrm{~b}-\mathrm{j}$ & -11.59 & $6.34 \mathrm{a}$ \\
\hline CIMMYT-HTN 2013/14-4492 & $6.87 \mathrm{a}$ & $5.261-\mathrm{t}$ & -23.44 & $6.06 \mathrm{abc}$ \\
\hline CIMMYT-HTN 2014/15-8 & $5.63 \mathrm{e}-\mathrm{o}$ & $3.88 \mathrm{w}$ & -31.08 & $4.75 \mathrm{hij}$ \\
\hline Basribey & $6.46 \mathrm{a}-\mathrm{e}$ & $5.99 \mathrm{~b}-\mathrm{j}$ & -7.28 & $6.22 \mathrm{ab}$ \\
\hline CIMMYT-HTN 2014/15-4 & $6.27 \mathrm{a}-\mathrm{g}$ & $6.14 \mathrm{a}-\mathrm{h}$ & -2.07 & $6.20 \mathrm{ab}$ \\
\hline CIMMYT-HTN 2014/15-6 & $5.46 \mathrm{~g}-\mathrm{s}$ & $5.36 \mathrm{~h}-\mathrm{t}$ & -1.83 & $5.41 \mathrm{efg}$ \\
\hline Esperia & $5.29 \mathrm{~h}-\mathrm{t}$ & $5.66 \mathrm{e}-\mathrm{n}$ & 6.99 & $5.47 \mathrm{~d}-\mathrm{g}$ \\
\hline CIMMYT-HTN 2013/14-4488 & $6.63 \mathrm{a}-\mathrm{d}$ & $5.06 \mathrm{k}-\mathrm{u}$ & -23.68 & $5.84 \mathrm{a}-\mathrm{f}$ \\
\hline CIMMYT-HTN 2013/14-4490 & $6.06 \mathrm{a}-1$ & $5.91 \mathrm{c}-\mathrm{j}$ & -2.48 & 5.98 a-e \\
\hline Syrena & $5.04 \mathrm{k}-\mathrm{u}$ & $5.55 \mathrm{f}-\mathrm{r}$ & 10.12 & $5.29 \mathrm{fgh}$ \\
\hline CIMMYT-HTN 2014/15-2 & $5.93 \mathrm{~b}-\mathrm{j}$ & $5.87 \mathrm{~d}-\mathrm{k}$ & -1.01 & $5.90 \mathrm{a}-\mathrm{e}$ \\
\hline CIMMYT-HTN 2014/15-9 & $5.72 \mathrm{e}-\mathrm{n}$ & $5.64 \mathrm{e}-\mathrm{o}$ & -1.40 & $5.68 \mathrm{~b}-\mathrm{f}$ \\
\hline Krasunia & 5.65 e-n & $5.56 \mathrm{f}-\mathrm{q}$ & -1.59 & $5.60 \mathrm{c}-\mathrm{f}$ \\
\hline Nota & $6.76 \mathrm{ab}$ & $5.62 \mathrm{e}-\mathrm{p}$ & -16.86 & $6.19 \mathrm{ab}$ \\
\hline Gelibolu & $5.83 \mathrm{~d}-\mathrm{m}$ & $4.74 \mathrm{q}-\mathrm{v}$ & -18.70 & $5.28 \mathrm{fgh}$ \\
\hline Tina & $6.09 \mathrm{a}-1$ & $4.71 \mathrm{r}-\mathrm{V}$ & -22.76 & $5.40 \mathrm{efg}$ \\
\hline Dropia & $4.65 \mathrm{~s}-\mathrm{V}$ & $5.021-u$ & 7.96 & $4.83 \mathrm{~h} 1 \mathrm{j}$ \\
\hline CIMMYT-HTN 2014/15-7 & $4.67 \mathrm{~s}-\mathrm{V}$ & $4.03 \mathrm{vw}$ & -13.70 & $4.35 \mathrm{j}$ \\
\hline CIMMYT-HTN 2013/14-4464 & $5.62 \mathrm{e}-\mathrm{p}$ & $5.95 \mathrm{~b}-\mathrm{j}$ & 5.87 & $5.78 \mathrm{a}-\mathrm{f}$ \\
\hline Yubileynaya 100 & $6.39 \mathrm{a}-\mathrm{f}$ & 5.38 e-n & -15.80 & 5.88 a-e \\
\hline Kate A1 & $5.94 \mathrm{~b}-\mathrm{j}$ & $5.53 \mathrm{f}-\mathrm{v}$ & -6.90 & $5.73 \mathrm{~b}-\mathrm{f}$ \\
\hline Saraybosna & $5.00 \mathrm{~m}-\mathrm{u}$ & $4.72 \mathrm{q}-\mathrm{v}$ & -5.60 & 4.86 hij \\
\hline CIMMYT-HTN 2014/15-10 & $4.59 \mathrm{t}-\mathrm{w}$ & $4.28 \mathrm{uvw}$ & -6.75 & $4.43 \mathrm{ij}$ \\
\hline CIMMYT-HTN 2014/15-3 & $5.15 \mathrm{j}-\mathrm{t}$ & $5.89 \mathrm{c}-\mathrm{k}$ & 14.37 & $5.52 \mathrm{c}-\mathrm{f}$ \\
\hline Golia & $4.78 \mathrm{p}-\mathrm{V}$ & $5.14 \mathrm{j}-\mathrm{t}$ & 7.53 & 4.96 gh1 \\
\hline Tekirdağ & $4.87 \mathrm{n}-\mathrm{u}$ & $4.79 \mathrm{o}-\mathrm{V}$ & 1.64 & $4.83 \mathrm{hij}$ \\
\hline Pehlivan & $5.53 \mathrm{f}-\mathrm{r}$ & $5.64 \mathrm{e}-\mathrm{o}$ & 1.99 & $5.58 \mathrm{c}-\mathrm{f}$ \\
\hline Flamura-85 & $6.09 \mathrm{a}-1$ & $4.94 \mathrm{n}-\mathrm{u}$ & -18.88 & $5.51 \mathrm{c}-\mathrm{f}$ \\
\hline Mean & 5.76 & 5.31 & -7.81 & \\
\hline MSE & 17.86148 & & & \\
\hline
\end{tabular}

that had the highest GY in the LS date was CIMMYTHTN 2014/15-4 (6.14 tha-1). This line was followed by CIMMYT-HTN 2014/15-1 (6.06 t ha $\left.\mathrm{a}^{-1}\right)$, Basribey (5.99 $\left.\mathrm{t} \mathrm{ha}^{-1}\right)$, CIMMYT-HTN 2013/14-4464 (5.95 t ha $\left.^{-1}\right)$, CIMMYT-HTN 2013/14-4490 (5.91 t ha-1), CIMMYT-HTN 2014/15-3 (5.89 $\left.\mathrm{t} \mathrm{ha}^{-1}\right)$, CIMMYTHTN 2014/15-2 (5.87 $\mathrm{t} \mathrm{ha}^{-1}$ ) (Table 2). Basribey cultivar and CIMMYT-HTN 2014/15-5, CIMMYTHTN 2014/15-4, CIMMYT-HTN 2013/14-4490 were the highest GY both in NS and LS (Table 2).

Membrane thermostability (MT-\%): There were significant differences $(\mathrm{P} \leq 0.01)$ among the mean of bread wheat cultivars for the MT (Table 3 ). That is one of the methods that are recommended in the 
Table 3- Means and significance groups of genotypes' some examined traits

\begin{tabular}{|c|c|c|c|c|}
\hline Genotype & $\begin{array}{l}M T \\
(\%) \\
\end{array}$ & $\begin{array}{l}C T \\
\left({ }^{\circ} C\right) \\
\end{array}$ & $\begin{array}{l}L C C \\
(S P A D)\end{array}$ & $\begin{array}{l}S C \\
\left(m m o l m^{-2} s^{-1}\right)\end{array}$ \\
\hline Nota & $50.270 \mathrm{e}$ & $20.000 \mathrm{a}-\mathrm{d}$ & $43.233 \mathrm{efg}$ & $58.133 \mathrm{~b}-\mathrm{g}$ \\
\hline Kate A1 & $44.670 \mathrm{~h}$ & $19.333 \mathrm{~b}-\mathrm{e}$ & 48.867 a-f & $79.200 \mathrm{bcd}$ \\
\hline Basribey & $39.960 \mathrm{~m}$ & $20.667 \mathrm{ab}$ & $44.367 \mathrm{c}-\mathrm{g}$ & $72.500 \mathrm{~b}-\mathrm{f}$ \\
\hline Gelibolu & $30.930 \mathrm{uv}$ & $21.000 \mathrm{ab}$ & 46.367 a-f & $32.733 \mathrm{efg}$ \\
\hline Esperia & $20.000 \mathrm{~A}$ & $20.667 \mathrm{ab}$ & $50.233 \mathrm{a}-\mathrm{e}$ & $93.500 \mathrm{bc}$ \\
\hline Saraybosna & $33.670 \mathrm{t}$ & $20.667 \mathrm{ab}$ & $53.000 \mathrm{ab}$ & $166.800 \mathrm{a}$ \\
\hline Syrena & $49.530 \mathrm{f}$ & $20.000 \mathrm{a}-\mathrm{d}$ & 48.633 a-f & $33.133 \mathrm{efg}$ \\
\hline Flamura 85 & $30.930 \mathrm{uv}$ & $20.000 \mathrm{a}-\mathrm{d}$ & 49.667 a-e & $55.000 \mathrm{~b}-\mathrm{g}$ \\
\hline Krasunia & $35.000 \mathrm{~s}$ & $22.000 \mathrm{a}$ & 49.367 a-e & $95.633 \mathrm{ab}$ \\
\hline Dropia & $37.130 \mathrm{o}$ & $21.000 \mathrm{ab}$ & $50.733 \mathrm{a}-\mathrm{d}$ & $78.300 \mathrm{~b}-\mathrm{e}$ \\
\hline Tina & $26.660 \mathrm{y}$ & $20.000 \mathrm{a}-\mathrm{d}$ & 50.233 a-e & $64.100 \mathrm{~b}-\mathrm{g}$ \\
\hline Golia & $31.040 \mathrm{u}$ & $21.333 \mathrm{ab}$ & 47.300 a-f & $32.733 \mathrm{efg}$ \\
\hline Tekirdağ & $10.580 \mathrm{~B}$ & $21.000 \mathrm{ab}$ & $45.667 \mathrm{c}-\mathrm{g}$ & $93.933 \mathrm{bc}$ \\
\hline Pehlivan & $42.830 \mathrm{i}$ & $20.333 a b c$ & $41.833 \mathrm{fg}$ & $38.000 \mathrm{~d}-\mathrm{g}$ \\
\hline Yubileynaya 100 & $54.230 \mathrm{~d}$ & $21.000 \mathrm{ab}$ & $50.900 \mathrm{a}-\mathrm{d}$ & $55.633 \mathrm{~b}-\mathrm{g}$ \\
\hline CIMMYT-HTN 2014/15-1 & $44.590 \mathrm{~h}$ & $20.333 \mathrm{abc}$ & 49.367 a-e & $61.567 \mathrm{~b}-\mathrm{g}$ \\
\hline CIMMYT-HTN 2014/15-2 & $66.250 \mathrm{a}$ & $19.333 \mathrm{~b}-\mathrm{e}$ & 49.367 a-e & $56.600 \mathrm{~b}-\mathrm{g}$ \\
\hline CIMMYT-HTN 2014/15-3 & $37.380 \mathrm{n}$ & $20.000 \mathrm{a}-\mathrm{d}$ & $45.500 \mathrm{c}-\mathrm{g}$ & $55.900 \mathrm{~b}-\mathrm{g}$ \\
\hline CIMMYT-HTN 2014/15-4 & 40.9701 & $19.333 \mathrm{~b}-\mathrm{e}$ & $46.100 \mathrm{~b}-\mathrm{f}$ & 33.400 efg \\
\hline CIMMYT-HTN 2014/15-5 & $58.010 \mathrm{~b}$ & $17.667 \mathrm{e}$ & 48.733 a-f & $46.133 \mathrm{~d}-\mathrm{g}$ \\
\hline CIMMYT-HTN 2014/15-6 & $50.300 \mathrm{e}$ & $19.333 \mathrm{~b}-\mathrm{e}$ & $51.467 \mathrm{ac}$ & $39.533 \mathrm{~d}-\mathrm{g}$ \\
\hline CIMMYT-HTN 2014/15-7 & $46.110 \mathrm{~g}$ & $19.333 \mathrm{~b}-\mathrm{e}$ & 49.800 a-e & $52.667 \mathrm{~b}-\mathrm{g}$ \\
\hline CIMMYT-HTN 2014/15-8 & $43.010 \mathrm{i}$ & $18.000 \mathrm{de}$ & $44.333 \mathrm{c}-\mathrm{g}$ & $51.167 \mathrm{c}-\mathrm{g}$ \\
\hline CIMMYT-HTN 2014/15-9 & $56.820 \mathrm{c}$ & $17.667 \mathrm{e}$ & $38.300 \mathrm{~g}$ & $79.100 \mathrm{bcd}$ \\
\hline CIMMYT-HTN 2014/15-10 & $36.660 \mathrm{p}$ & 18.333 cde & $53.300 \mathrm{a}$ & $28.767 \mathrm{fg}$ \\
\hline CIMMYT-HTN 2013/14-4464 & $23.960 \mathrm{z}$ & $20.667 \mathrm{ab}$ & $45.700 \mathrm{c}-\mathrm{f}$ & $43.633 \mathrm{~d}-\mathrm{g}$ \\
\hline CIMMYT-HTN 2013/14-4488 & $26.890 \mathrm{y}$ & $20.333 \mathrm{abc}$ & $44.033 \mathrm{~d}-\mathrm{g}$ & $55.433 \mathrm{~b}-\mathrm{g}$ \\
\hline CIMMYT-HTN 2013/14-4489 & $30.670 \mathrm{v}$ & $21.000 \mathrm{ab}$ & 48.700 a-f & $78.500 \mathrm{bcd}$ \\
\hline CIMMYT-HTN 2013/14-4490 & $35.670 \mathrm{r}$ & $21.000 \mathrm{ab}$ & 47.600 a-f & $43.867 \mathrm{~d}-\mathrm{g}$ \\
\hline CIMMYT-HTN 2013/14 4492 & $41.730 \mathrm{k}$ & $21.000 \mathrm{ab}$ & 50.333 a-e & $71.267 \mathrm{~b}-\mathrm{g}$ \\
\hline MSE & 0.022 & 1.292 & 12.820 & 466.613 \\
\hline
\end{tabular}

MT, membrane thermostability; CT, canopy temperature; LCC, leaf chlorophyll content (LCC); SC, stomatal conductance (SC); MSE, mean squared error

tolerant plant selection to stress condition(s). The method used for the identification of membrane permeability depends on the principle of the determination of the number of ions that leak into the apoplastic fluid from cytoplasm as a result of function disorder in cell membrane caused by injury (Gusta et al 2003). The study revealed that the MT increased in stress conditions, which means that the genotypes with lower cell injury are more tolerant to heat stress conditions.

In this study, mean MT values had a large variation between 10.580 to $66.250 \%$ (Table 3). This might be a result of different genetic structures of the genotypes used in the research. The highest MT value was detected in CIMMYT-HTN 2014/ 15-2 (66.250\%). It was followed by CIMMYT- 
HTN 2014/15-5, CIMMYT-HTN 2014/15-9 and Yubileynaya 100 (58.010\%, 58.200\% and 54.230\%, respectively). It can be said that the heat-temperature stress tolerance of these genotypes for the MT values is higher than others. In the study, the lowest MT value was taken from Tekirdağ (10.580\%) and Esperia $(20.000 \%)$ cultivars. Our findings on genotypes have similar with the reports of Sikder et al (1999), Blum et al (2001), Hasan et al (2007), Yildirım et al (2009), Khan et al (2013) and Khan et al (2015) who revealed that the MT of wheat genotypes that are exposed to high-temperature stress caused by LS which depends on the genotype.

Canopy temperature $\left(\mathrm{CT}-{ }^{\circ} \mathrm{C}\right)$ : In the variance analysis made for the $\mathrm{CT}$, differences between the genotypes have been found as $\mathrm{P} \leq 0.01$ significant (Table 3). The high CT causes the increase in respiration of the plants and consequently decreases the net photosynthesis rate. For this reason, the genotypes which have the lower CT under the same ecological conditions are advantageous considering plant development.

The $\mathrm{CT}$ in all genotypes was varied between (17.667 ${ }^{\circ} \mathrm{C}$ to $22.000{ }^{\circ} \mathrm{C}$ ) (Table 3). Accordingly, differences occur that reach to $4.333{ }^{\circ} \mathrm{C}$ between $\mathrm{CT}$ of the wheat genotypes that grown under the same ecological conditions. This can be a result of different reactions of tested genotypes to the hightemperature stress caused by late sowing. Similar to our findings, Ray \& Ahmad (2015) revealed that CTs of wheat genotypes at the post-anthesis stage are different. Also, the researchers revealed that CT can be used as a selection criterion under the hightemperature stress conditions.

In our study, it was found that CIMMYT-HTN 2014/15-9 and CIMMYT-HTN 2014/15-5 (17.667 ${ }^{\circ} \mathrm{C}$ ) had the lowest $\mathrm{CT}$ among bread wheat genotypes. TheselineswerefollowedbyCIMMYT-HTN2014/158 (18.000 $\left.{ }^{\circ} \mathrm{C}\right)$, CIMMYT-HTN 2014/15-10 (18.333 ${ }^{\circ} \mathrm{C}$ ), CIMMYT-HTN 2014/15-7, CIMMYT-HTN 2014/15-6, CIMMYT-HTN 2014/15-4, CIMMYTHTN 2014/15-2 and Kate A-1 $\left(19.333^{\circ} \mathrm{C}\right)$. The results revealed that the CIMMYT origin genotypes have the lower $\mathrm{CT}$ and more tolerant to the high temperatures.
Our findings in accordance with Sikder \& Paul (2010) who are found that high heat tolerant wheats have the lower CT than those of the sensitive. On the other hand, the highest CT was measured in Krasunia $\left(22.000{ }^{\circ} \mathrm{C}\right)$, Golia $\left(21.333{ }^{\circ} \mathrm{C}\right)$, Dropia $\left(21.000{ }^{\circ} \mathrm{C}\right)$, Tekirdağ $\left(21.000^{\circ} \mathrm{C}\right)$, CIMMYT-HTN 2013/14-4490 $\left(21.000^{\circ} \mathrm{C}\right)$, CIMMYT-HTN 2013/14-4492 (21.000 $\left.{ }^{\circ} \mathrm{C}\right)$, CIMMYT-HTN 2013/14-4489 (21.000 $\left.{ }^{\circ} \mathrm{C}\right)$, Yubileynaya $100\left(21.000{ }^{\circ} \mathrm{C}\right)$ and Gelibolu $(21.000$ $\left.{ }^{\circ} \mathrm{C}\right)$. In the light of these results, it was realized that Krasunia, Dropia, Tekirdağ, Gelibolu, Esperia cultivars' CT were affected by high temperatures. Besides, CIMMYT-HTN 2013/14-4490, CIMMYTHTN 2013/14-4492, CIMMYT-HTN 2013/14-4489 and CIMMYT-HTN 2013/14-4464 lines are believed to have a lower tolerance in terms of the CT.

Leaf chlorophyll content (LCC-SPAD): The mean of the LCC differences of the genotypes which are exposed to heat stress in late sowing were determined as $\mathrm{P} \leq 0.01$ significant (Table 3 ). The LCC values were changed between (38.300 to 53.300 SPAD) and had been a large variation (Table 3 ). This might be a result of different genetic structures of the wheat genotypes used in the research. Similar to our findings, Javed et al (2014) revealed that the LCC of cultivars in high-temperature stress were significantly different. In our study, the highest LCC was detected in CIMMYT-HTN 2014/15-10 (53.300 SPAD). It was followed by Saraybosna (53.000 SPAD), CIMMYT-HTN 2014/15-6 (51.467 SPAD), Yubileynaya 100 (50.990 SPAD) and Dropia (50.773 SPAD). These results revealed that CIMMYT origin lines which are known to be tolerant to the hightemperature since they have the high LCC. Our findings are similar to the findings of Reynolds et al (1996), Nawaz et al (2013) and Feng et al (2014). The lowest LCC among the genotypes was found in CIMMYT-HTN 2014/15-9 with (38.300 SPAD). It was followed by Pehlivan (41.833 SPAD) and Nota (43.233 SPAD). In a general evaluation considering the LCC of other genotypes, it was observed that some lines which are known to be tolerant to the high-temperature(s) (CIMMYT-HTN２013/144488, CIMMYT-HTN 2014/15-8, CIMMYT-HTN 2014/15-3 and CIMMYT-HTN 2013/14-4464) had 
the very low LCC $(44.033,44.333,45.500,45.700$ SPAD, respectively) (Table 3). On the other hand, it can be mentioned that there was not a certain correlation between the LCC and high-temperature stress and this trait depends on genotype, ecology, and their interactions and used growing techniques.

Stomatal conductance (SC- $\mathrm{mmol} \mathrm{m} \mathrm{m}^{-2} \mathrm{~s}^{-1}$ ): The $\mathrm{SC}$ is known as a physiological selection criterion used in estimating gas exchange such as $\mathrm{CO}_{2}$ absorption thoroughly to the leaves and water loss with transpiration depending on stomata pore (Pask et al 2012). Munjal \& Rana (2003) revealed that the low of CT and high SC during the grain filling period of bread wheat genotypes under the hightemperature(s) can be basic morpho-physiological criteria for the high GY. According to the results of variance analysis in the study, the difference between the genotypes has been statistically $(\mathrm{P} \leq 0.01)$ found significant for the SC (Table 3). The $\mathrm{SC}$ in the bread wheats was shown a large variation between $\left(25.200\right.$ to $\left.166.800 \mathrm{mmol} \mathrm{m}^{-2} \mathrm{~s}^{-1}\right)$. This variation shows that bread wheat genotypes do not respond equally to heat- temperature stress in terms of the SC. The highest SC values were detected in Saraybosna (166.800 mmol m $\left.\mathrm{m}^{-2} \mathrm{~s}^{-1}\right)$, Krasunia (95.633 $\left.\mathrm{mmol} \mathrm{m}^{-2} \mathrm{~s}^{-1}\right)$, Tekirdağ $\left(93.933 \mathrm{mmol} \mathrm{m}^{-2}\right.$ $\left.\mathrm{s}^{-1}\right)$, Esperia ( $\left.93.500 \mathrm{mmol} \mathrm{m}^{-2} \mathrm{~s}^{-1}\right)$ cultivars (Table 3). Golia cultivar $\left(25.200 \mathrm{mmol} \mathrm{m}^{-2} \mathrm{~s}^{-1}\right)$ had the lowest stomatal conductance. This cultivar was followed by CIMMYT-HTN 2014/15-10 (28.767 $\mathrm{mmol} \mathrm{m}^{-2}$ $\mathrm{s}^{-1}$ ), Gelibolu (32.733 $\mathrm{mmol} \mathrm{m}^{-2} \mathrm{~s}^{-1}$ ), Syrena with (33.133 $\mathrm{mmol} \mathrm{m}^{-2} \mathrm{~s}^{-1}$ ) and CIMMYT-HTN 2014/15$4\left(33.400 \mathrm{mmol} \mathrm{m}^{-2} \mathrm{~s}^{-1}\right)$. It has been realized that the flag leaf SC values of tested genotypes were found as low during the post-anthesis period. This may be caused by the senescence of flag leaves in the postanthesis period in which measurements have been made. Similar to our findings, Bahar et al (2009) reported that SC value of durum wheats' (Triticum durum Desf.) $294 \mathrm{mmol} \mathrm{m}^{-2} \mathrm{~s}^{-1}$ at the early milk stage, and it decreased to $225 \mathrm{mmol} \mathrm{m}^{-2} \mathrm{~s}^{-1}$ at the end of the milk stage and to $167 \mathrm{mmol} \mathrm{m}^{-2} \mathrm{~s}^{-1}$ at the early dough stage, and this resulted from senescence of flag leaf after anthesis.

\section{Conclusions}

As a summary, Dropia, Nota, CIMMYT-HTN 2014/15-2, CIMMYT-HTN 2014/15-6, CIMMYTHTN 2014/15-10 were found as prominent for all investigated traits, except for the GY. It is possible that to use of these genotypes as genitor(s) or progenitor(s) in the wheat breeding programs for the heat-temperature stress tolerance. The (5) genotypes (Basribey, CIMMYT-HTN 2013/144490, CIMMYT-HTN 2014/15-1, CIMMYT-HTN 2014/15-4, CIMMYT-HTN 2014/15-5, respectively) were higher in terms of the GY at the NS and LS. On the other hand, these genotypes were found as the prominent for the examined heat tolerance parameters. In order to develop the heat tolerant and to get higher of the GY, a comprehensive wheat breeding program can be suggested which includes multiple crossing among them with the selection method considered for the heat tolerance, yield and yield components like the physiological parameters such as MT, CT, LCC and SC against to the hightemperature stress in wheat.

\section{Acknowledgements}

This work was supported by the Office of Scientific Research Projects of Tekirdağ Namık Kemal University (Project No. NKUBAP.00.24.AR.14.15).

\section{References}

Bahar B, Yildirim M \& Barutcular C (2009). Relationships between stomatal conductance and yield components in spring durum wheat under Mediterranean conditions. Notulae Botanicae Horti Agrobotanici Cluj-Napoca 37(2): 45-48

Balla K, Zegi M R, Li Z, Békés F, Ze S B \& Veisz O (2011). Quality of winter wheat in relation to heat and drought shock after anthesis. Czech Journal Food Sciences 29: 117-128

Bluementhal C, Bekes F, Gras P W, Barlow E W R \& Wrigley C W (1995). Influence of wheat genotypes tolerant to the effects of heat stress on grain quality. Cereal Chemistry 72: 539-544

Blum A, Klueva N \& Nguyen H T (2001). Wheat cellular thermotolerance is related to yield under heat stress. Euphytica 117(2): 117-123 
Din R, Subhani G, Ahmad N, Hussain M \& Rehman A (2010). Effect of temperature on development and grain formation in spring wheat. Pakistan Journal of Botany 42: 899-906

Feng B, Liu P, Li G, Dong S T, Wang F H, Kong L A \& Zhang J W (2014). Effect of heat stress on the photosynthetic characteristics in flag leaves at the grain-filling stage of different heat-resistant winter wheat varieties. Journal of Agronomy and Crop Science 200: 143-155

Gusta L V, Wisniewski M, Nesbitt N T \& Tanino K T (2003). Factors to consider in artificial freeze tests. Acta Horticolturae 618: 493-507

Hasan M A, Ahmed J U, Bahadur M M, Haque M M \& Sikder S (2007). Effect of late planting heat stress on membrane thermostability, proline content and heat susceptibility index of different wheat cultivars. Journal of the National Science Foundation 35(2): 109-117

Hays K, Maynard I, Thomas O \& Bawden M (2007). Sources and types of confidence identified by worldclass sport performers. Journal of Applied Sport Psychology 19: 434-456

Javed N, Ashraf M, Qurainy F A \& Akram N A (2014). Integration of physio-biochemical processes at different phenological stages of wheat (Triticum aestivum L.) plants in response to heat stress. Pakistan Journal of Botany 46(6): 2143-2150

Khan S U, Din J U, Gurmani A R, Qayyum A \& Khan H (2013). Heat tolerance evaluation of wheat (Triticum aestivum L.) genotypes based on some potential heat tolerance indicators. Journal of the Chemical Society Pakistan 35(3): 647-653

Khan S U, Din J U, Qayyum A, Jan N E \& Jenk M A (2015). Heat tolerance indicators in Pakistani wheat (Triticum aestivum L.) genotypes. Acta Botanica Croatica 74(1): 109-121

Kirby E J M, Appleyard M \& Fellowes G (1985). Variation in development of wheat and barley in response to sowing date and variety. Journal of Agricultural Science 104: 383-396

Kosina P, Reynolds M P, Dixon J \& Joshi A K (2007). Stakeholder perception of wheat production constraints, capacity building needs and research partnerships in developing countries. Euphytica 157: 475-483

Longnecker N, Kirby E J M \& Robson A (1993). Leaf emergence, tiller growth, and apical development of nitrogen-deficient spring wheat. Crop Science 33: 154-160

Mathur S \& Jajoo A (2014). Physiological mechanisms and adaptation strategies in plants under changing the environment (P. Ahmad and M.R. Wani Eds.): Volume 1, Chapter 8: Effects of heat stress on growth and crop yield of wheat (Triticum aestivum L.), Springer Science+Business Media, New York, pp. 163-191

Modhej A, Farhoudi R \& Afrous A (2015). Effect of postanthesis heat stress on grain yield of barley, durum and bread wheat genotypes. Journal of Scientific Research and Development 2(6): 127-131

Mohammadi V, Qannadha M R, Zali A A \& Yazdi-Samadi B (2004). Effect of post-anthesis heat stress on head traits of wheat. International Journal of Agriculture and Biology 6(1): 42-44

Munjal R \& Rana R K (2003). Evaluation of physiological traits in wheat (Triticum aestivum L.) for terminal high-temperature tolerance. In: Proceedings of the Tenth International Wheat Genetics Symposium, Classical and Molecular Breeding, 1-6 September, Poestum, Italy, pp. 804-805

Nawaz A, Farooq M, Cheema S A \& Wahid A (2013). Differential response of wheat cultivars to terminal heat stress. International Journal of Agriculture and Biology 15: 1354-1358

Pask A J D, Pietragalla J, Mullan D M \& Reynolds M P (2012). Physiological breeding II: A field guide to wheat phenotyping, D.F.: CIMMYT, Mexico

Ray J \& Ahmed U (2015). CT effects on yield and grain growth of different wheat genotypes. Journal of Agriculture and Veterinary Sciences 8(7): 48-55

Reynolds M P, Balota M, Delgado M I B, Amani I \& Fischer R A (1994). Physiological and morphological traits associated with spring wheat yield under hot, irrigated conditions. Australian Journal of Plant Physiology 21: 717-730

Reynolds M P, Nagarajan S \& McNab A (1996). Increasing yield potential in wheat: Breaking the barriers, D.F.: CIMMYT, Mexico

Reynolds M P, Ortiz-Monasterio J I \& McNab A (2001). Application of Physiology in Wheat Breeding, D.F.: CIMMYT, Mexico

Sikder S \& Paul N K (2010). Effects of post-anthesis heat stress on stem reserves mobilization, depression and floret sterility of wheat cultivars. Bangladesh Journal Botany 39(1): 51-55 
Sikder S, Ahmed J U, Hossain T, Miah M A K \& Hossain M M (1999). Membrane thermostability, grain growth and contribution of pre-anthesis stem reserve to grain weight under late seeded condition. Thai Journal of Agricultural Science 32(4): 465-473

Steel R G D \& Torrie J H (1960). Principles and Procedures of Statistics. (With Special Reference to the Biological Sci.), McGraw-Hill Book Company, New York, Toronto, London

Wang W, Vinocur B, Shoseyov O \& Altman A (2001). Biotechnology of plant osmotic stress tolerance: Physiological and molecular considerations. Acta Horticulturae 560: 285-292

Wang W X, Vincur B \& Altman A (2003). Plant responses to drought, salinity and extreme temperatures: towards genetic engineering for stress tolerance. Planta 218: 1-14

Wardlaw I F, Blumenthal C, Larroque O \& Wrigley C W (2002). Effects of chronic heat stress and heat shock on grain weight and flour quality in wheat. Functional Plant Biology 29: 25-34

Yıldırım M, Bahar B, Koç M \& Barutçular C (2009). Membrane thermal stability at different developmental stages of spring wheat genotypes and their diallel cross populations. Journal of Agricultural Science 15(4): 293-300

Zadoks J C, Chang T T \& Konzak C F (1974). A decimal code for growth stages of cereals. Weed Research 14: 415-421 